Original Articles

\title{
A case series of 7 Sri Lankan patients with type 1 spinal muscular atrophy
}

\author{
Shree R Banstola ${ }^{1}$, Nirmala D Sirisena ${ }^{2}$, Dulika S Sumathipala ${ }^{2}$, *Vajira H W Dissanayake ${ }^{3}$ \\ Sri Lanka Journal of Child Health, 2016; 45(4): 247-249 \\ DOI: http://dx.doi.org/10.4038/sljch.v45i4.8029 \\ (Key-words: Developmental delay, hypotonia, SMN1 gene, SMN2 gene, spinal muscular atrophy)
}

\section{Introduction}

Spinal muscular atrophy (SMA) is an autosomal recessive neuromuscular disorder with an incidence of 1 in 6000 to 1 in 10,000 live births ${ }^{1}$. It is characterized by degeneration of the anterior horn cells of the spinal cord, leading to progressive symmetrical proximal muscle weakness and atrophy ${ }^{1,2,3}$. About $95-98 \%$ of patients have a homozygous deletion of exons 7 and 8 in the telomeric copy of the survival motor neuron 1 gene $(S M N 1)^{4,5}$. Another 2-5\% are compound heterozygotes for deletion of exons 7 and 8 of $S M N 1$ and a point mutation in $S M N 1$ gene $e^{4,5}$. The clinical and genetic pattern of SMA has not previously been reported in Sri Lanka. Genetic testing for SMA was introduced in Sri Lanka in 2007 since when 39 patients clinically suspected of SMA were referred for testing. Of these, 7 (18\%) had homozygous deletions in exons 7 and 8 . We describe the clinical and genetic features of these 7 SMA patients.

\section{Case description}

The 7 patients in this case series were referred for genetic evaluation between 2007 and 2014 to 2 genetic referral centres viz. Human Genetics Unit, Faculty of Medicine, University of Colombo and Asiri Centre for Genomic and Regenerative Medicine, Asiri Surgical Hospital, Colombo. The clinical features of the 7 patients were obtained at the time of referral for genetic evaluation. The authors did not have access to follow up clinical data on disease progression. Molecular genetic testing was performed after obtaining written informed consent. DNA was extracted using Wizard genomic DNA purification kit (Promega, USA) according to manufacturer's instructions. Polymerase chain

${ }^{1}$ Scientist, ${ }^{2}$ Clinical Geneticist, ${ }^{3}$ Medical Geneticist, Human Genetic Unit, University of Colombo, Sri Lanka

*Correspondence: vajirahwd@hotmail.com

(Received on 11 October 2015: Accepted after revision on 20 November 2015)

The authors declare that there are no conflicts of interest

Personal funding was used for the project.

Open Access Article published under the Creative

Commons Attribution CC-BY CC (P) reaction (PCR) to amplify the SMN1 gene exons 7 and 8 and digestion of the amplified PCR products using restriction enzymes were carried out based on the validated method described by $\mathrm{H}$. Scheffer et $a l^{6}$. This is a well-established test to detect homozygous deletions of exon 7 and 8. In addition, in the diagnostic assay, internal positive and negative control samples were used and those samples gave the expected result always, indicating that the method used was $100 \%$ sensitive and specific.

Ages of the 7 cases ranged from 20 days to 9 months. Four $(57.1 \%)$ of the 7 patients were females. Two (28.6\%) patients had respiratory difficulty while all patients had proximal muscle weakness in all 4 limbs. All the patients had SMA subtype 1 since the age of onset of their symptoms was within the first 6 months of life. Five (71.4\%) patients presented for genetic evaluation within the first 6 months of life and the remaining $2(28.6 \%)$ presented at 7 and 9 months of age, respectively. The clinical profile of the patients are summarized in Table 1.

\section{Discussion}

Lefebvre et al. ${ }^{7}$ in 1995 were the first to identify and characterize the $S M N$ gene which they termed 'survival motor neuron' within the SMA candidate region on chromosome 5q13. They demonstrated deletion or disruption of the gene in 226 of 229 patients with SMA. In the same year, Wirth et al. ${ }^{8}$ presented their experience with 109 prenatal diagnoses performed in 91 families at risk of SMA by use of polymorphic microsatellites in the region 5q11.2-q13.3. Of the 109 prenatal diagnoses performed, 29 fetuses were diagnosed to be at more than $99 \%$ risk of developing the disease, while in 7 additional pregnancies no exact prediction could be made due to a recombination event in 1 parental haplotype. The phenotypic heterogeneity of SMA is striking with clinical severity ranging from SMA types 1 to 4 . Four types of SMA are recognized depending on the age of onset, the maximum muscular activity achieved, and survivorship viz. type I, severe infantile acute SMA, or WerdnigHoffman disease; type II, or infantile chronic SMA; type III, juvenile SMA, or Wohlfart-KugelbergWelander disease; and type IV, or adult-onset SMA. All types are caused by recessive mutations in the SMN1 gene. 
Table 1: Clinical Profile of the SMA patients

\begin{tabular}{|c|c|c|l|c|c|c|}
\hline $\begin{array}{c}\text { Case } \\
\text { No. }\end{array}$ & $\begin{array}{c}\text { Age of } \\
\text { presentation }\end{array}$ & Sex & \multicolumn{1}{|c|}{ Clinical features } & $\begin{array}{c}\text { Clinical } \\
\text { subtype }\end{array}$ & $\begin{array}{c}\text { Parental } \\
\text { Consanguinity }\end{array}$ & $\begin{array}{c}\text { Family history of } \\
\text { affected siblings }\end{array}$ \\
\hline 1 & 20 days & Male & Hypotonia & SMA1 & Yes & Yes \\
\hline 2 & 9 months & Female & $\begin{array}{l}\text { Delayed motor } \\
\text { milestones }\end{array}$ & SMA1 & No & No \\
\hline 3 & 7 months & Female & $\begin{array}{l}\text { Delayed motor } \\
\text { milestones }\end{array}$ & SMA1 & Yes & No \\
\hline 4 & 2 months & Female & Hypotonia & SMA1 & No & Yes \\
\hline 5 & 6 months & Female & $\begin{array}{l}\text { Delayed motor } \\
\text { milestones }\end{array}$ & SMA1 & No & Yes \\
\hline 6 & 1 month & Male & Hypotonia & SMA1 & No & Yes \\
\hline 7 & 5 months & Male & $\begin{array}{l}\text { Delayed motor } \\
\text { milestones }\end{array}$ & SMA1 & No & No \\
\hline
\end{tabular}

In this case series, 5 patients presented for genetic evaluation within 6 months of age. They had hypotonia with proximal muscle weakness in all 4 limbs and delayed motor milestones. Based on the age of onset and severity of symptoms, they were clinically classified as SMA type 1 . The remaining 2 patients presented to the genetics clinic at 7 and 9 months of age, respectively with delayed motor milestones. The 7 months old child was hypotonic and unable to sit unsupported while the 9 months old child had no head control at presentation and his electromyogram showed chronic changes compatible with SMA indicating a prolonged disease course. They were both clinically categorized as SMA type 1 due to onset of symptoms presumably before 6 months of age.

In SMA type 1, the disease progression is rapid with increased complications resulting in early death. In severe disease, neonates may have feeding and respiratory difficulties. Incidence reports of SMA subtypes in the scientific literature show that there is a relatively higher prevalence of SMA type 1 compared to types 2,3 and $4^{9}$. It is reported that around $60 \%$ have type 1 disease and $30 \%$ type $2^{10}$. Findings in this case series agree with the published literature. However, it remains to be further elucidated whether there are actually fewer patients with the other subtypes or whether these patients are not referred for genetic evaluation probably due to milder phenotypes. The other less severe SMA types 2, 3 and 4 are postulated to be determined by the presence of the copy numbers of SMN2 gene, which is a centromeric copy of the SMN1 gene. The SMN2 copy number is inversely related to the severity of the SMA disease spectrum ${ }^{11}$. As only 7 out of the 39 patients referred tested positive for the homozygous deletion in exons 7 and 8, we plan to carry out direct sequencing of the SMN1 gene in the remaining patients with suspected SMA to exclude any underlying point mutations. It is possible that they may be compound heterozygotes due to deletion of exons 7 and 8 and a point mutation in SMN1 gene. A study which investigated the genetic basis of SMA subtypes showed that compound heterozygous mutations account for approximately $4.1 \%, 6.5 \%$ and $17.6 \%$ of SMA types 1,2 and 3 , respectively ${ }^{4}$. In addition, it is also possible that some of the negative cases who were referred with a clinical suspicion of SMA may in fact be having some other type of neuromuscular disorder causing the hypotonia and developmental delay, not necessarily SMA.

Among the 7 patients, 4 had a family history of an affected elder sibling who had died within 6 months of age with features suggestive of SMA type 1. None of them had undergone genetic testing to confirm the diagnosis. Overall, the small number of positive cases reported in this case series over a period of 8 years may essentially be a reflection of the low rate of referral of patients with clinical suspicion of SMA for genetic evaluation. These findings indicate that there is a dire need for further improvement and dissemination of genetic testing and counseling services within the country to control and prevent the burden of SMA. Information regarding future recurrence risk, carrier testing, prenatal diagnosis and alternative reproductive options are key issues that need to be addressed.

Definitive treatment modalities are at present not available for patients affected with SMA. However, once a genetic diagnosis is established, genetic counseling and education regarding the natural history and progression of the disease, supportive management and clinical trial opportunities can be offered to patients and their families ${ }^{12}$. This paper highlights the need for clinicians to utilize genetic services as an important tool in the holistic management of patients with SMA. Even in the presence of the milder phenotypes, establishing a genetic diagnosis and providing appropriate genetic counseling for affected families with regards to 
preventing recurrences in future pregnancies are suggested.

It is essential to establish a genetic diagnosis and provide appropriate genetic counseling services for families affected with SMA in order to prevent recurrences in future pregnancies. Medical professionals should be encouraged to utilize genetic services as an important tool in the holistic management of patients with SMA.

\section{References}

1. D'Amico A, Mercuri E, Tiziano FD, Bertini E. Spinal muscular atrophy. Orphanet Journal of Rare Diseases 2011; 6: 71. http://dx.doi.org/10.1186/1750-1172-6-71 PMid: 22047105 PMCid: PMC3231874

2. Sugarman EA, Nagan N, Zhu H, Akmaev VR, Zhou Z, Rohlfs EM, et al. Pan-ethnic carrier screening and prenatal diagnosis for spinal muscular atrophy: clinical laboratory analysis of $>72,400$ specimens. European Journal of Human Genetics 2012; 20: 2732.

http://dx.doi.org/10.1038/ejhg.2011.134

PMid: 21811307 PMCid: PMC3234503

3. Skalsky AJ, McDonald CM. Prevention and management of limb contractures in neuromuscular diseases. Physical Medicine and Rehabilitation Clinics of North America 2012; 23: 675-87. http://dx.doi.org/10.1038/ejhg.2011.134 PMid: 21811307 PMCid: PMC3234503

4. Wirth B, Herz M, Wetter A, Moskau S, Hahnen E, Rudnik-Schoneborn S, et al. Quantitative analysis of survival motor neuron copies: identification of subtle SMN1 mutations in patients with spinal muscular atrophy, genotype-phenotype correlation, and implications for genetic counseling. American Journal of Human Genetics 1999; 64: 1340-56.

http://dx.doi.org/10.1086/302369

PMid: 10205265 PMCid: PMC1377870

5. Gambardella A, Mazzei R, Toscano A, Annesi G, Pasqua A, Annesi F, et al. Spinal muscular atrophy due to an isolated deletion of exon 8 of the telomeric survival motor neuron gene. Annals of Neurology 1998; 44: 836-9.

http://dx.doi.org/10.1086/302369

PMid: 10205265 PMCid: PMC1377870
6. Scheffer H, Cobben JM, Matthijs G, Wirth B. Best practice guidelines for molecular analysis in spinal muscular atrophy. European Journal of Human Genetics 2001; 9: 484-91.

http://dx.doi.org/10.1038/sj.ejhg.5200667

PMid: 11464239

7. Lefebvre S, Burglen L, Reboullet S, Clermont O, Burlet P, Viollet L, et al. Identification and characterization of a spinal muscular atrophy-determining gene. Cell 1995; 80: 155-65.

http://dx.doi.org/10.1016/00928674(95)90 $\underline{460-3}$

8. Wirth B, Rudnik-Schoneborn S, Hahnen E, Rohrig D, Zerres K. Prenatal prediction in families with autosomal recessive proximal spinal muscular atrophy (5q11.2-q13.3): molecular genetics and clinical experience in 109 cases. Prenatal Diagnosis 1995; 15: 407-17.

http://dx.doi.org/10.1002/pd.1970150503 PMid: 7644431

9. Bouhouche A, Benomar A, Birouk N, Bouslam N, Ouazzani R, Yahyaoui M, et al. High incidence of SMN1 gene deletion in Moroccan adult-onset spinal muscular atrophy patients. Journal of Neurology 2003; 250: 1209-13.

http://dx.doi.org/10.1007/s00415-003

0186-1

PMid: 14586604

10. Ogino S, Wilson RB, Gold B. New insights on the evolution of the SMN1 and SMN2 region: simulation and meta-analysis for allele and haplotype frequency calculations. European Journal of Human Genetics 2004; 12: 1015-23. http://dx.doi.org/10.1038/sj.ejhg.5201288 PMid: 15470363

11. Oskoui M, Kaufmann P. Spinal muscular atrophy. Neurotherapeutics. 2008; 5: 499506.

http://dx.doi.org/10.1016/j.nurt.2008.08.00

PMid: 19019300 PMCid: PMC4514700

12. Biros I, Forrest S. Spinal muscular atrophy: untangling the knot? Journal of Medical Genetics 1999; 36: 1-8.

PMid: 9950358 PMCid: PMC1762953 